\title{
Introduction to the Conference on Law and Happiness
}

\author{
Eric A. Posner and Cass R. Sunstein
}

Economists who make normative proposals traditionally assume that policy should advance "efficiency," usually in the Kaldor or Hicks sense, which defines efficiency in terms of whether the project's winners can hypothetically compensate the project's losers. A compensation criterion is used because it can be based on ordinal utilities, which puts a smaller information burden on the decision maker than cardinal utilities do. Ordinal utilities, unlike cardinal utilities, can (in principle) be inferred from observations of consumer behavior. By seeing how people trade off goods, willingness-to-pay (or willingness-to-accept) amounts can be derived and summed, so that alternative policy outcomes can be easily compared.

This approach has received a great deal of criticism over the decades, but it has survived mainly because no alternative method has commanded widespread agreement. In recent years, however, a small group of economists and psychologists have argued that an alternative method is available. This method, often called the "happiness approach," relies on surveys that ask people to rate their happiness on a scale. Econometric analysis then finds correlations between ratings on the scale and various characteristics or experiences of the survey respondents-wealth, income, family relationships, and so forth. Though still regarded with skepticism in many quarters, the happiness approach has scored some notable successes. The various factors that are correlated with happiness appear to be robust: they recur in different surveys and are correlated

ERIC A. POSNER is the Kirkland and Ellis Professor of Law at the University of Chicago Law School. CASS R. SUNSTEIN is the Felix Frankfurter Professor of Law at Harvard Law School.

[Journal of Legal Studies, vol. 37 (June 2008)]

(C) 2008 by The University of Chicago. All rights reserved. 0047-2530/2008/370S2-0001\$10.00 
with other factors that are plausibly linked to happiness such as physical well-being as measured with clinical tests.

In addition, many of the findings have a certain plausibility, while at the same time deviating from the results of willingness-to-pay and willingness-to-accept measures. Happiness improves with wealth but only to a point, and people are less happy when their neighbors are wealthier than they are. Happiness is correlated with health, but the happiness levels of people who suffer grievous injuries rebound with the passage of time. Happy people have friends and families, but adults with teenagers are less happy than adults with younger or older children. Educated and politically engaged people are happier.

The idea that policy should focus on happiness rather than preference orderings is hardly new. Indeed, the happiness view predates the preference-orderings view. Jeremy Bentham advocated a form of utilitarianism that maximized pleasures and minimized pains, an idea that is similar, though not identical, to the premise that self-reported happiness measures should be used. Economists subsequently abandoned this view in favor of ordinal utility functions. But the Benthamite approach never really went away. It has lurked at the margins of mainstream economic thought for decades. The most famous example is the Easterlin paradox. Richard Easterlin (1973) was the first to observe that self-reported happiness is correlated with wealth at the individual level but not, above a threshold, at the aggregate level: he found that happiness does not appear to increase with gross domestic product in wealthy countries (this finding has been challenged; see Stevenson and Wolfers 2008).

More recent work has exploited improved data sets; much of it is oriented toward public policy. Much work continues to investigate the methodological foundations of happiness research, with some authors (for example, Kahneman 2000) expressing concerns about the reliability or accuracy of the happiness surveys and proposing alternatives. Most of the public-policy-oriented work has focused on the implications of the research for structuring political institutions (for example, Frey and Stutzer 2002), for evaluating government projects (for example, Van Praag and Baarsma 2005), and for determining legal damages for various types of injuries (for example, Clark and Oswald 2002). ${ }^{1}$

1. Applications in the legal literature have been sparse. See, for example, Bagenstos and Schlanger (2007), Bronsteen, Buccafusco, and Masur (2008), Huang and Swedloff (2008), Posner and Sunstein (2005), and Warner (2008). 
The current issue of the Journal of Legal Studies contains papers delivered at a conference on the new happiness research and its implications for law and public policy, which was held at the University of Chicago Law School on June 1 and 2, 2007. The purpose of the conference was to encourage greater collaboration across disciplines and reflection on the implications of happiness research for law and public policy. Several of the papers (Haidt, Seder, and Kesebir; Hsee, Xu and Tang; Nussbaum; Dolan and Peasgood; Stevenson and Wolfers) explore continuing methodological challenges to the happiness approach, the empirical data, and the implications for public policy in a general sense. The other papers address the implications of happiness research for specific areas of the law, including the determination of damages (Oswald and Powdthavee; Sunstein; Ubel and Loewenstein), crime (Cohen), tax (Weisbach), and cost-benefit analysis (Adler and Posner).

We thank the John M. Olin Progam in Law and Economics at the University of Chicago Law School for providing financial support for this conference.

\section{REFERENCES}

Bagenstos, Samuel R., and Margo Schlanger. 2007. Hedonic Damages, Hedonic Adaptation, and Disability. Vanderbilt Law Review 60:745-97.

Bronsteen, John, Christopher Buccafusco, and Jonathan S. Masur. 2008. Hedonic Adaptation and the Settlement of Civil Lawsuits. Columbia Law Review 108: 1516-49.

Clark, Andrew E., and Andrew J. Oswald. 2002. A Simple Statistical Method for Measuring How Life Events Affect Happiness. International Journal of Epidemiology 31:1139-44.

Easterlin, Richard A. 1973. Does Money Buy Happiness? Public Interest 30: 3-10.

Frey, Bruno S., and Alois Stutzer. 2002. Happiness and Economics: How the Economy and Institutions Affect Human Well-Being. Princeton, N.J.: Princeton University Press.

Huang, Peter H., and Rick Swedloff. 2008. Authentic Happiness and Meaning at Law Firms. Syracuse Law Review 58:335-50.

Kahneman, Daniel. 2000. Experienced Utility and Objective Happiness: A Moment-Based Approach. Pp. 673-92 in Choices, Values, and Frames, edited by Daniel Kahneman and Amos Tversky. Cambridge: Cambridge University Press.

Posner, Eric A., and Cass R. Sunstein. 2005. Dollars and Death. University of Chicago Law Review 72:537-98. 
S4 / THE JOURNAL OF LEGAL STUdies / VOLUme 37 (2) / JUNE 2008

Stevenson, Betsey, and Justin Wolfers. 2008. Economic Growth and Happiness: Reassessing the Easterlin Paradox. Brookings Papers on Economic Activity, spring, pp. 1-102.

Van Praag, Bernard M. S., and Barbara E. Baarsma. 2005. Using Happiness Surveys to Value Intangibles: The Case of Airport Noise. Economic Journal 115:224-46.

Warner, Daniel M. 2008. Uses of Subjective Well-Being in Local Economic and Land Use Policy. Journal of Land Use and Environmental Law 23:263-303. 